\title{
Algumas notas comparativas sôbre Direito Social no Brasil e nos Estados Unidos*
}

\author{
Paul Griffith Garland
}

\section{I - Observações gerais}

Alguns dos aspectos mais destacados do Direito Social Brasileiro, em comparação com o norte-americano, são os seguintes: 1) a existência de leis escritas que tratam detalhadamente da relação de emprêgo: 2) o fato de serem estas leis federais, ao invés de estaduais: 3) que as Leis são executadas em um sistema de tribunais federais especializados em Direito Social. Em contraste, até muito recentemente, o Direito Social nos Estados Unidos tem sido em grande parte a aplicação dos princípios não escritos do direito costumeiro, e a grande parte do direito, seja escrito ou costumeiro, tem sido estadual e não federal. Além disso não existem tribunais especiais para direito social ${ }^{1}$.

Esta orientação pode ser explicada nos têrmos da história norte-americana: Ainda que a sindicalização dos operários tenha começado há quase 200 anos, os meios de comunicação entre tais grupos sindicais eram difíceis até recentemente. Por isso, tanto os empregados como os empregadores com quem êles tratavam, consideravam o problema do emprêgo um problema local. Assinı foi que

* Trabalho apresentado ao Seminário de Legislação Social, do Prof. A. F. Cesarino Júnior, na Faculdade de Direito da Unjversidade de São Paulo.

1. Existem agências de direito administrativo federais e estaduais que são especializadas em assuntos de direito social, mas não constituem tribunais. 
quando qualquer das partes desejava proteger os seus direitos em juízo, ou obter novos direitos por meio de legislação, recorria ao govêrno do Estado (e não ao da Nação) e ao qual ainda recorre hoje quanto a muitas normas legais.

Aos problemas resultantes das relações entre a classe operária e a patronal, os tribunais estaduais aplicavam os princípios do direito costumeiro geral ou comum, sendo êste naturalmente o direito que êles conheciam. Os resultados dêsse fato foram desfavoráveis ao movimento de organização dos operários em Sindicatos ${ }^{2}$, e assim os sindicatos necessitavam apelar para o auxílio do poder legislativo e ademais aprender a proteger seus próprios interêsses sem o auxílio do govêrno.

Ainda que os princípios restritivos do direito costumeiro se achem hoje abandonados em grande parte, tornase êsse direito importante para resolver dificuldades legais normais resultantes do contrato de emprêgo, tais como o pagamento dos salários estipulados, se o empregado A recebeu as férias a que tinha direito, ou, por outras palavras, para a interpretação legal do contrato de emprêgo.

Sumàriamente, as diferenças gerais entre os sistemas brasileiro e norte-americano podem ser resumidos assim:

\section{Brasil}

Lei escrita detalhada

Legislação Federal

\section{Estados Unidos}

Direito costumeiro não escrito de princípios gerais, (mas com legislação crescente nos últimos 30 anos).

Legislação Estadual (mas com crescente legislação federal sôbre certos aspectos nos últimos 30 anos).

2. Alguns exemplos da aplicação infeliz dos princípios antiquados do direito costumeiro, atualmente de interêsse histórico: 
Tribunais Federais de

\author{
Tribunais Estaduais \\ de Jurisdição comum. ${ }^{3}$
}

Trabalhos Especializados

Mais uma diferença importante a notar-se é que muitos dos detalhes enumerados na Legislação brasileira ficam a critério das partes (é dizer, empregado e empregador), nos Estados Unidos; isto pode ser resumidamente explicado, dêste modo: Em muitos aspectos o movimento sindical norte-americano, apresentando-se bem antes da época atual de preocupação pública com problemas trabalhistas, não recebeu apôio, nem nos princípios do direito costu-

a. Quanto à indenização de acidentes de trabalho:

1. "Aceitação do risco" (Assumption of the risk). Presume-se que o empregado tem conhecimento dos riscos relacionados com o emprêgo e oferece-se apesar dêsses riscos, assim aceitando-o por conta própria.

2. "Empregado colega" (Fellow servant rule): Caso o acidente seja da culpa de outro empregado, o empregador não pode ser responsabilizado.

3. "Negligência Contributória" (contributory Negligence) : Se o acidentado contribuiu em qualquer respeito ao acidente, o empregador não é responsável.

4. "Negligência do empregador": O empregado tem que demonstrar esta, cabendo-lhe, pois, o ônus da prova. Se a culpa não pode ser demonstrada não é responsável.

b. Restrição à liberdade para sindicalizar.

1. "Conspiração" (Conspiracy) : Sindicatos considerados agrupamentos ilegais com fím de elevar os salários.

2. "Liberdade de contrato" (Freedom of contract): Sindicatos considerados uma violação do direito de o empregador individual vender seus serviços por conta própria e, outrossim, do direito de o empregador tratar com os operários individualmente.

c. Quanto ao exercício de atividades sindicais:

1. "Cercado de estacas" (Picketing): Considerado uma violação da ordem pública ou do direito de a indústria funcionar.

2. Greve: Idem Idem.

3. Deve-se notar o papel importante da Comissão Nacional de Relações de Trabalho ou N. L. R. B. (v. pág. 289), e também de entidades estaduais análogas. 
meiro, inflexíveis demais ou não apropriados para questões de trabalho, nem no poder legislativo, não convencido da prudência de uma classe operária organizada. Assim foi que os trabalhadores norte-americanos, lutando para proteger seus interêsses durante os 150 anos antes da chegada da legislação do "New Deal" de 1932 a 1940, que reconheceu tais atividades como legítimas, aprenderam a negociar com o empregador para obter seus desejos por meio do contrato de trabalho. Éste processo de negociação entre empregado e empregador é hoje conhecido como o "collective bargaining process" (processo de negociação coletiva) e forma o coração da relação de emprêgo nos Estados Unidos hoje. É neste processo que as partes "legislam" para si as normas para regular as condições de trabalho, tais como férias, salários, processos para resolver disputas, quadro de carreira, horário, seguro de saúde, preferências dos empregados antigos, etc. Outrossim, resulta que, em geral, a lei está no segundo plano nos Estados Unidos, e quando esteja no primeiro, normalmente serve para estabelecer sòmente condições gerais, nos têrmos das quais as partes poderão negociar, mas nã̉o para limitar a sua capacidade de estipular seu próprio contrato, que represente a sua resolução dos problemas peculiares a elas.

Não parece muito difícil explicar a diferença de método empregado no Brasil. Em um país latino, segundo o sistema da lei codificada no qual a conveniência social de normas legais é determinada pelo legislador e não pelo juiz, é lógico que leis detalhadas sejam promulgadas. Acrescentando a isło a aparição bastante recente do problema do operário industrial em um país onde a escravidão durou até 1888 e que permaneceu bàsicamente agrícola até recentemente, e a falta de uma tradição de autodireção entre grupos trabalhistas ${ }^{4}$, a maior especificação

4. A. F. Cesarino JúnIor, Direito Social Brasileiro, São Paulo, 1953, 3. a edição, Pág. 121, afirmando que na época 1888-1930 quase não existiam sindicatos no Brasil. 
da lei pode ser não sòmente explicada mas justificada, pelo menos até que o movimento sindical se adapte aos métodos de "self government" autodireção e ao conceito de "collective bargaining" (negociação coletiva).

$O$ fato de ser federal o direito social no Brasil deve-se pelo menos a dois fatôres: primeiro, por ser federal a maior parte da legislação importante do país e, segundo, porque o Brasil reconhece na relação do trabalho um problema nacional, próprio para regulamentação nacional.

É interessante notar que o reconhecimento do trabalho como um objeto próprio de legislação federal apareceu aproximadamente ao mesmo tempo em ambos os países ${ }^{5}$, isto é, por volta de $1930^{6}$. Talvez seja verdadeiro também afirmar que em ambos a consideração do problema trouxe consigo a consciência de que foram necessários esforços para assegurar os direitos básicos para o trabalhador, para conseguir o reconhecimento, nos têrmos da Constituição brasileira, dos princípios da justiça social ${ }^{7}$. Se no Brasil a necessidade para legislação federal resultou da aparição súbita do trabalhador industrial como problema de importância, nos Estados Unidos resultou da compreensão de que os conceitos do direito costumeiro, a aplicação da lei escrita que existia e a atitude conservadora dos tribunais com a orientação do direito costumeiro, não eram adequados para assegurar ao trabalhador os

5. Nos Estados Unidos, o "Sherman Anti-Trust Act of 1890" tinha sido aplicado aos problemas trabalhistas e o "Clayton Anti-Trust Act of 1914" continha disposições expressas sôbre trabalho. Não obstante, a primeira lei nacional tratando de trabalho como tal pode ser considerada a "Lei dos Empregados Ferroviários" (Railway Labor Act) de 1926.

6. A. F. Cesarino JÚNIOR, op. cit., p. 121, citando legislação e a criação do Ministério do Trabalho, Industria e Comércio.

7. Artigo 145, "conciliando a liberdade de iniciativa com a valorização do trabalho humano". 
direitos básicos para êle enfrentar o empregador em condições de igualdade no processo de "collective bargaining".

\section{II - Desenvolvimento histórico}

Antes da primeira lei federal importante em 1926, decisões judiciais em muitos Estados, e ainda do Supremo Tribunal Federal dos Estados Unidos, tinham de fato feito muito para dificultar, aos sindicatos tratarem efetivamente, com a classe patronal. Foi decidido que o empregador poderia negar reconhecimento ao sindicato $\mathrm{e}$ a tratar com êle ${ }^{8}$ e que o empregador poderia interferir na organização de sindicatos ${ }^{9}$, incluindo uso do chamado contrato do cachorro amarelo (Yellow dog contract) no qual o empregado prometia não fazer-se membro de qualquer sindicato enquanto durasse a relação do emprêgo ${ }^{10}$. O empregador podia discriminar entre os membros e os não membros dos sindicatos ${ }^{11}$ e assim quebrar o poder do sindicato. Em geral foi fácil obter "injunções" (injunctions) 12 para restringir atividades dos trabalhadores, tais

8. Truax v. Corrigan, 257 U.S. 312, 1921, considerando inconstitucional uma lei estadual limitando "injunções" em dessídios trabalhistas.

9. Ibid. Isto incluiu o direito de organizar o chamado "sindicato da emprêsa" (Company Union), o qual seria dominado pelo empregador.

10. Não sòmente foi tal contrato considerado executável mas também o Supremo Tribunal Federal considerou inconstitucional a legislação estadual proibindo tais contratos. Coppage V. Kansas, 236 U.S. 1, 1915.

11. Adair V. United States, 208, U.S. 161, 1908.

12. A injunção é uma ordem de um tribunal mandado o cumprimento ou não cumprimento de certo ato ou atos. A falta de cumprimento sujeita o violador a um processo chamado "contumácia" (comtempt of court) normalmente perante o mesmo juiz de quem partiu a ordem original. Se julgado culpado por êle, multas ou ainda prisão podem ser impostas. 
como greves e tentativas de organizarem-se em sindicatos ${ }^{13}$. O próprio Supremo Tribunal Federal contribuiu para criar um ambiente judicial desfavorável ao crescimento dos sindicatos. Na mesma época em que o Supremo limitou o conceito de comércio interestadual para a aplicação da legislação "anti-trust" à indústria ${ }^{14}$, ampliou o conceito de comércio inter estadual ("interstate commerce") para sustentar a aplicação de tal legislação a atividades sindicais. Resultou dêste ponto de vista que a emprêsa tinha a seu favor a "injunção" contra uma grande variedade de atividades trabalhistas ${ }^{15}$ e que podia pleitear perdas e danos dos sindicatos e de seus membros nos têrmos da legislação "anti-trust" 16 .

Assim, a situação era a de que os empregadores tinham direitos de bastante alcance para defender os seus interêsses contra os sindicatos, enquanto que os sindicatos tinham só uma oportunidade limitada de organizar-se de um modo eficaz e de obter os seus desejos de um modo que não seria considerado ilegal.

Deve ser destacado que uma vez que o sindicato tivesse um contrato válido com um empregador, podia executálo satisfatòriamente nos tribunais. O problema foi obter bastante fôrça para que a emprêsa estivesse disposta a celebrar tal contrato. Foi em resposta a êste problema que apareceu a maior parte da legislação federal e esta-

13. Um aspecto importante foi não sòmente o conservativismo dos tribunais, mas também o fato de que uma "injunção temporària" (temporary injunction) foi frequentemente concedida, baseada sòmente na apresentação do caso pelo empregador. A violação de tais "injunções" também sujeitou os culpados às penas contumácias.

14. United States, v.E.c. Knight Co., 156 U.S. 1 1895: Decidido: Fabricação para comércio interestadual é uma atividade local e não parte de tal comércio, e como tal está fora do âmbito do poder do congresso de regular na legislação "anti-trust".

15. In re Debs, 158 U.S. 546, 1895: Decidido que trabalho em fabricação de produtos para comércio interestadual faz parte de tal comércio.

16. Lowe V. Lawor, 208 U.s. 214, 1908. 
dual. Esta legislação tinha por objetivo elevar o sindicato a uma posição em que pudesse negociar com a emprêsa com êxito, mas em geral não continha normas legais compulsórias para serem incluídas no contrato de trabalho. A legislação federal norte-americana tem objetivado especialmente, fornecer regras básicas como um "background", nos têrmos do qual as partes negociarão. A lei federal tem como preocupação fundamental assegurar que os contratantes tratem entre si de um modo justo, e neste respeito procura garantir que os contratos celebrados sejam em verdade contratos livremente combinados entre partes mais ou menos equilibradas quanto as vantagens em negociar, sem que qualquer delas goze de uma vantagem injusta com relação à outra.

$O$ primeiro passo importante ${ }^{17}$ para conferir à classe trabalhista os direitos necessários foi o "Railway Labor Act of 1926" (Lei dos Empregados Ferroviários de 1926) ${ }^{18}$ o qual garantiu aos empregados ferroviários o direito de escolher os seus representantes para o processo de "collective bargaining" e, como interpretado pelos tribunais, obrigou a emprêsa a tratar com êsses representantes, assim sancionando a organização de sindicatos e o processo de "collective bargaining" como socialmente desejáveis. Em 1932 veio o "Norris-La Guardia Act" 19, que dificultou o emprego da "injunção" contra atividades trabalhistas e que estipulou não ser executável o contrato de "cachorro amarelo" (Yellow Dog Contract). Ùltimamente aparece-

17. Uma tentativa para restringir o uso da "injunção" contra atividades operárias foi feita no "Clayton Anti-Trust Act of 1914". Não obstante, foi interpretado de um modo restrito e consequentemente não foi eficaz. No mesmo sentido, leis estaduais restringindo o uso da "injunção" foram muitas vêzes consideradas inconstitucionais pelos tribunais estaduais.

18. 44 United States Statutes at Large 1926. E interessante notar que no Brasil também o empregado ferroviário recebeu atenção cêdo: a lei 4.682 de 1923, estabelecendo institutos de pensões e aposentadorias.

19. 41 United States at Large 10, 1923. 
ram o "Wagner Act of 1935" 20 e seu sucessor de 1947, o "Taft-Hartley Act ${ }^{21}$. Em breve, estas duas leis garantiram a proteção seguinte ao movimento trabalhista norteamericano: ${ }^{22}$ o empregador tem de reconhecer um sindicato devidamente constituído como o representante dos trabalhadores para "collective bargaining" e tem de tratar com êle, e não com os empregados individualmente. A disposição concomitante é a de que todos os trabalhadores têm o direito de unir-se em sindicatos. É proibido ao empregador interferir de qualquer modo nas atividades do sindicato. Êle não pode restringir, controlar, interferir, ou coagir o estado de membro em qualquer sindicato, nem pode agir de qualquer modo contra membros, dos sindicatos, como por exemplo, demissão ou redução de salários ${ }^{23}$. Tais atos são denominados como "práticas trabalhistas injustas" (unfair labor practices) e podem ser restringidas.

Outrossim, certos atos de parte do trabalhador constituem práticas trabalhistas injustas e podem ser restringidas. Neste respeito, a lista foi bastante aumentada pelo "Taft-Hartley Act", e atualmente inclui: 1. ${ }^{\circ}$ ) a greve de simpatia ${ }^{24} ; 2 .{ }^{\circ}$ ) o "boycott" secundário ${ }^{25} ; 3 . .^{\circ}$ ) a greve de

20. O título oficial: "National Labor Relations Act of 1935" 49 United States Statutes at Large 457, 1935. $1947 "$

21. O título oficial. "Labor Management Relations Act of

22. Deve ser destacado também que a atitude do Supremo Tribunal Federal também mudou, e que além de considerar constitucional a legislação trabalhista do "New Deal" (com exceção das provisões de "National Industrial Recovery Act"), concluiu que a legislação "AntiTrust" não foi aplicável às atividades dos sindicatos. United States V Hucheson, 312 U.S. 219, 1941.

23. Uma provisão parecida acha-se no artigo 543 da Consolidação das Leis do Trabalho.

24. Isto é, apoiando grevistas contra outra emprêsa.

25. O "boycott", o mesmo que em português, é a não-compra e não negociação de produtos produzidos pela emprêsa tomando parte em disputa trabalhista. O "boycott secundário" é executado por trabalhadores que não tomam parte direta na disputa. 
jurisdição ${ }^{26} ; 4 .^{\circ}$ ) falta de negociar "coletivamente" com o empregador da parte do sindicato.

Para assegurar que o sindicato verdadeiramente represente os trabalhadores, não sòmente é proibida a intervencão da emprêsa, mas também aos trabalhadores são fornecidas garantias importantes: $10^{\mathrm{a}}$ decidir por votação secreta se desejam formar-se em sindicato. Se a decisão fôr afirmativa ${ }^{27}$, ouvir os argumentos de todos os sindicatos interessados em ter a sua filiação; $2 .^{\text {a }}$ escolher por votação secreta o sindicato ao qual desejam filiar-se ou expressar o seu desejo de ser um sindicato próprio e não filiado ${ }^{28}$.

Estas disposições e outras da lei são executadas por uma agência especial do govêrno federal chamada a "National Labor Relations Board" (NLRB) ${ }^{29}$, cujo título (Comissão Nacional de Relações de Trabalho) também indica a preocupação da lei federal com a relação entre o trabalhador e a emprêsa e não com os detalhes do próprio contrato.

Esta Comissão com natureza jurídica semelhante à de uma autarquia brasileira, mas com independência consideràvelmente maior para desenvolver sua própria política na

26. Uma greve resultando da disputa entre dois sindicatos sôbre qual deve ser o representante para negociação coletiva.

27. Neste respeito, deve notar-se que nos têrmos do "Taft-Hartley Act", abstenções são consideradas votos contra o sistema de sindicalização compulsória para todos os empregados da emprêsa (Union Shop), de modo que uma maioria absoluta dos elegíveis a votar é necessária. Na vigência do "Wagner Act" sòmente a maioria dos votantes era preciso, facilitando a decisão em favor da sindicalização compulsória

28. Outrossim, a votação secreta é garantida para cancelar o mandato de um sindicato como representante para negociação coletiva.

29. Agências estaduais semelhantes, com funções variáveis existem em muitos Estados. A sua jurisdição é limitada ao comércio intraestadual e consequentemente não é tão importante para a economia nacional. 
órbita de sua jurisdição, isto é, nas questões das relações entre trabalhador e o empregador no comércio interestadual (e não as questões legais ordinárias, tais como o efeito legal de artigos do contrato). Na jurisdição da NLRB cabem as disposições mencionadas acima, inclusive as práticas trabalhistas injustas. Ademais ela fiscaliza as votações secretas dos trabalhadores nas quais êles decidem sindicalizar-se ou não, e escolhem o sindicato. Outro poder importante da NLRB, é a escôlha da unidade sindical conveniente para negociação coletiva, isto é, se tal negociação deve ser no nível local, estadual, ou nacional.

A comissão compõe-se de cinco membros, escolhidos pelo Presidente da República com a aprovação do Senado, para um mandato de seis anos, mandato êsse que não coincide, para garantir a continuidade. Ela não forma parte de qualquer Ministério e é de fato uma agência administrativa com completa autonomia, que combina a função judicial de apreciar fatos, com a função legislativa de estabelecer normas legais para serem observadas. Assim, não sòmente pode estabelecer política por meio de portarias, etc., mas também atua de um modo judicial apreciando os fatos e depois decidindo se êles constituem ou não uma violação das normas estabelecidas ou pela NLRB, ou pela legislação básica. No exercício dễste duplo poder, a NLRB é quase isenta de revisão de suas decisões pelos tribunais, e a própria legislação federal estipula que as decisões em questões de fato sejam finais se apoiadas em provas, e, como interpretado pelo Supremo Tribunal Federal, isto veio a significar que quase nunca existe a possibilidade de uma apreciação judicial dos fatos ${ }^{30}$. Ainda quando a questão é de lei, o Supremo Tribunal tem sido muito favorável à não revisibilidade da decisão da NLRB ${ }^{31}$,

30. Pode-se notar que êste tipo de organização é típico da entidade administrativa nos Estados Unidos e que entidades semelhantes dêste " $4 .^{\circ}$ ramo de govêrno" existem para atividades como: aviação, comêrcio interestadual, normas de concorrências legítimas, rádio e televisão e outros. 
assim fornecendo um contraste marcante com o Brasil, onde as decisões administrativas são sempre sujeitas à revisão judicial, não sòmente quanto à lei aplicável mas também com uma independente apreciação judicial dos fatos.

Devido a suas características especiais como uma entidade independente, combinando funções judiciais e legislativas, não é possível comparar a NLRB com equivalente brasileira. Não obstante em certos respeitos ela é parecida com a Justiça de Trabalho e com o Ministério Público do Trabalho e a Procuradoria da Justiça do Trabalho.

A semelhança entre a NLRB e os Tribunais de Trabalho, limita-se ao fato de ambas resolverem questões legais no ramo de direito especializado de direito social e de terem ambas o que se pode considerar como representação classista entre seus membros. É importante repetir, não obstante, que a maior parte das questões trabalhistas nos Estados Unidos é resolvida ou pelo tribunal de competência geral, seja estadual ou federal, ou pelas partes mesmas. Nos procedimentos perante tais tribunais, as partes por sua conta própria normalmente oferecem testemunhas peritais (peritos) ou provas especiais para explicar problemas trabalhistas fora da experiência comum. Ademais, o tribunal mesmo pode chamar peritos por conta própria quando a complexidade do problema assim o exija. Estas testemunhas peritais representam, talvez, um equivalente ao sistema brasileiro de ter representantes do trabalhador e do empregador para servirem como "juízes".

A NLRB é mais uma entidade de representação classista que os tribunais norte-americanos, considerando que a maior parte de seus membros são escolhidos em consideração de seu conhecimento e contacto com questões trabalhistas, o que significa que são aptos a serem membros de grupos sindicais ou patronais ou advogados que têm

31. NLRB, V. Jones \& Laughlin Steel Corp. U.S. 1937; a primeira decisão importante aplicando o "Wagner Act", fornecendo a base, subsequentemente expandida em decisões posteriores. 
representado tais grupos. No entanto, membros para representar o público em geral, são também escolhidos e na seleção dos representantes mais ou menos classistas nenhum esfôrço especial é feito para contrabalançar o número de representantes. Em geral, todos os nomeados representam um ponto de vista mais ou menos em harmonia com o do Presidente da República, e assim são escolhidos para representar um modo de pensar, em vez de uma classe. Por isso é que a NLRB também emprega testemunhas de peritos em vez de experiência pessoal para resolver os problemas intrincados que the são apresentados. E mais uma vez vale repetir que a NLRB não tem jurisdição geral senão limitada.

Pessoalmente, entendemos que nada se ganha com o sistema brasileiro de tribunais especializados, embora reconheçamos que êle nada tem de especialmente defei. tuoso. Ao instituir um tipo de "testemunha pericial" por meio de representantes classistas como "juízes", o sistema brasileiro parece esquecer-se de que para emitir um julgamento pericial é necessário conhecimento pericial do ramo particular e não uma filiação geral de classe. Assim é que um juiz pertencente a um sindicato estivador não é particularmente qualificado para julgar os interêsses do petroleiro. Em tal caso, então, parece que seria preciso chamar um perito em petróleo, e, nesta hipótese, o juiz representante de empregados não ajuda muito a solução do problema. Quanto ao equilíbrio de interêsses de classe, parece que êste seria garantido pelos próprios litigantes. Em última análise, parece que caso os juízes classistas votem nos têrmos de classes, os seus votos cancelam-se e cabe ao juiz de direito decidir ${ }^{32}$.

O que se pode considerar o "tribunal" mais importante no direito trabalhista nos Estados Unidos não é um tribunal mas a chamada "Comissão Conciliatória Emprega-

32. Considerações iguais, mas de menos intensidade apresentam-se no Tribunal Regional e Tribunal Superior. 
dora" (Labor-Management Conciliation Committee). Lembre-se que as leis trabalhistas norte-americanas são muito menos detalhadas que as leis brasileiras. Resulta que cabe às partes criar a sua própria "legislação" social no contrato de trabalho, que é realizado por uma Comissão de Negociação Coletiva, composta de representantes de empregador e empregado, que redige o contrato. A Comissão de Conciliação também se compõe de representantes de ambos os lados e seu papel é resolver problemas resultantes, ou do contrato ou das condições gerais de trabalho, e assim evitar a necessidade de uma greve ou recurso a um tribunal. Neste respeito, pode ser notado que como o direito norte-americano deixa muito para ser determinado pelas partes no contrato, também deixa muitos problemas resultantes do contrato para serem resolvidos por elas ou deixados não resolvidos. O dissídio coletivo de natureza econômica está fora da jurisdição dos tribunais e da NLRB nos Estados Unidos. Por exemplo, um tribunal pode determinar o pagamento ou não pelo empregador do salário combinado no contrato, pois é questão legal. Mas se o contrato expirar e as partes não entrarem em acôrdo sôbre um novo salário, o tribunal não pode estabelecê-lo por conta própria, sendo a questão econômica e não legal. Assim cabe ao Sindicato e à Emprêsa encontrar a solução, em vez de tê-lo resolvido através de um tribunal, como no Brasil ${ }^{33}$.

As vêzes um processo de arbitramento é instaurado para suplementar a Comissão de Conciliação, com pessoas aceitáveis ao sindicato e à emprêsa, escolhidas para ajudar a resolver os problemas que aparecem. Normalmente, as decisões por arbitramento são facultativas e não obrigató-

33. Como a questão econômica nunca aparece no tribunal, resulta, "a fortiori", que tal decisão não poderia ser estendida a partes não presentes, como no Brasil. Êste princípio também se aplica aos acôrdos empregador-empregado para por fim a disputas. Só se aplicam aos que combinarem, e não, por exemplo, a outro sindicato na mesma atividade. 
rias, e por isso os árbitros são conhecidos como mediadores, já que o seu papel é tentar levar as partes a um acôrdo, em vez de prolatar uma decisão própria de natureza "judicial".

Neste respeito pode ser observado mais um exemplo da característica básica da legislação trabalhista norteamericana, de tentar ajudar as partes para elas próprias resolverem as dificuldades. $O$ govêrno federal tem, como parte de seu Ministério de Trabalho, uma entidade chamada o "Serviço Federal de Mediação", (Federal Mediation Service), cujos membros são disponíveis a pedido das partes para facilitar a solução de disputas ${ }^{34}$. Muitos Estados também têm tais serviços.

Assim é que os Estados Unidos também têm reconhecido a importância da conciliação mas têm dado a ela uma forma algo diferente. Enquanto no Brasil há duas oportunidades para conciliação no processo perante o Tribunal, nos Estados Unidos isto ocorre fora do Tribunal (ainda que com mediadores governamentais, às vêzes) e, não obstante ser um princípio básico do direito costumeiro tentar reconciliar as partes litigantes, nenhuma disposição especial existe no processo judicial para questões trabalhistas. Por outro lado, a função do Serviço Federal de Mediação pode ser comparada a do Ministério Público do Trabalho, que tem a responsabilidade de tentar a resolução extra-judicial dos dissídios coletivos.

Caso malogrem todos os esforcos para resolver a questão, os operários podem recorrer à greve. Como no Brasil, o direito de greve é quase ilimitado. Nem sempre foi assim entretanto, e, como mencionado acima, a tendência dos tribunais em conceder "injunções" restringindo greves foi um impedimento sério à eficácia sindical. Hoje, a greve pode ser controlada a pedido do empregador só em casos excepcionais, quando exista ameaça de dano a pessoas ou propriedade. Não obstante, o "Taft-Hartley

34. Ademais os seus membros podem aparecer voluntàriamente na disputa para oferecer os seus serviços. 
Act" introduziu algumas restrições no direito a greve, que talvez podem ser comparadas com a exigência brasileira de registro do processo no Tribunal Regional do Trabalho antes da entrada em greve. Estas disposições incluem não sòmente uma votação secreta dos trabalhadores sôbre a última oferta do empregador (e assim sôbre a decisão de entrar em greve) mas também aviso prévio de 60 dias da intenção de fazer greve ${ }^{35}$.

Até êste ponto tem sido destacada a diferença de objetivo da legislação social nos dois países, e tem sido indicado que por motivos históricos a própria legislação tem um papel maior no Brasil que nos Estados Unidos, ainda que, como será indicado oportunamente, os resultados obtidos por negociação coletiva nos Estados Unidos não sejam, no aspecto geral, tão diferentes das disposições legais brasileiras. Em resumo, parece que se pode concluir que o Direito Social brasileiro pertence muito mais ao campo de direito público, enquanto que o norte-americano é mais direito privado.

\section{III - Diferenças e semelhanças institucionais e conceituais}

Uma das melhores ilustrações da natureza do direito social acha-se no conceito do sindicato ${ }^{36}$. No Brasil o sindicato é uma organização que depende de autorização do govêrno para exercer as suas atividades. Também o sistema tem por fim a unidade sindical, com só um sindicato para cada categoria. Existem mais aspectos que indicam o interêsse mais ou menos direto do govêrno no sindicato, inclusive a exigência de submeter o orçamento sindical ao Ministério para aprovação, a arrecadação de

35. Nos casos de indústria de importância Nacional (tais como Carvão, Transportes, etc.), o Presidente da República pode obter uma “injunção" temporária contra greves quando representarem um perigo devido a uma situação de emergência nacional.

36. Nos Estados Unidos chama-se "Union" (União), pala,vra sem o conteúdo sindical do brasileiro "sindicato". 
fundos por meio de Impôsto Sindical, e a possibilidade da retirada do reconhecimento governamental.

Nos Estados Unidos o sindicato é uma associação particular de trabalhadores para lutar em favor de seus interêsses ${ }^{37}$. Pode formar-se e funcionar sem autorização do govêrno. Resulta que é possível, e de fato tem sido normal, existirem muitos sindicatos representando operários da mesma atividade industrial dentro de dada área geográfica ou ainda dentro do mesmo estabelecimento. Não obstante esta pluralidade sindical e concorrência resultante terem sido benéficas em incentivar cada sindicato concorrente a oferecer vantagens aos membros em perspectiva, algumas vêzes a concorrência tem sido ativa demais e não sòmente tem interrompido o trabalho mas também dificultado a apresentação de uma "frente única" para negociar coletivamente com o empregador. Para reduzir êstes problemas, e ao mesmo tempo manter o sistema plural, o sistema antes mencionado foi estabelecido sob supervisão da NLRB, com as disposições para a escôlha de filiação sindical para cada grupo de trabalhadores por votação secreta. $\mathrm{O}$ sindicato assim escolhido não é sòmente reconhecido pela emprêsa mas também pela NLRB como o representante próprio do grupo, o que, de certo modo, se aproxima do reconhecimento governamental do sistema brasileiro. Não obstante, deve notar-se que os dois maiores sindicatos norte-americanos são organizados por sistemas diferentes, um por especialidade ou artezanato (Federação Americana de Trabalho, ou A.F.L.) e o outro por indústria (Congresso de Organizações Industriais ou c.I.o.). Ambos os métodos foram aprovados pela NLRB, de modo que ainda é possível (mas ou menos usual) haver membros de sindicatos distintos trabalhando lado a lado na mesma emprêsa, pois o sistema continua sendo plural ${ }^{38}$.

37. Consequentemente é parecido à associação profissional brasileira.

38. Não obstante, um projeto para fundir a AFL e o cro foi há pouco aprovado pelos líderes de ambos os grupos, e se fôr aprovado 
Outros aspectos de atividade sindical nos Estados Unidos também indicam a sua natureza de agrupamento particular. Os seus fundos provêm principalmente das mensalidades dos membros, a importância da qual é estabelecida pelo próprio sindicato, e que consequentemente varia com o sindicato. Não há imposto sindical para o empregador, nem contribui o govêrno para os fundos sindicais. Mas as mensalidades podem ser retidas pelo empregador por conta do sindicato, se o contrato assim o estipular ${ }^{39}$, como fica descontado do salário o imposto sindical do empregado no Brasil.

Como mencionado acima, o coração do direito social nos Estados Unidos é a legislação particular que as partes estabelecem no contrato de trabalho. Isto não quer dizer que a lei (lei estadual especialmente) não seja importante para assegurar direitos ao trabalhador. Muitas vêzes a lei facilita para o trabalhador a obtenção de cláusulas no contrato. Não obstante, é no contrato de trabalho, e não na lei como no Brasil, que a maior parte das relações entre empregado e empregador é regulada, e aqui é que aparece a grande flexibilidade e a discreção reservadas às partes.

É no contrato que o quadro para salário, horário diário e horário semanal são combinados para cada empregador e cada sindicato. Nele se estipula a remuneração para trabalho extraordinário. Em geral, uma remuneração maior é estabelecida para o trabalho noturno. Indenização no caso de demissão é muitas vêzes combinada por contrato. Sistemas de segurança de saúde (relacionado com o emprêgo ou não) com prêmios pagos pelo empregador, pelo sindicato, ou por ambos, são normais. Quadros organizados dos empregados em carreira, benefícios para maternidade, quadros para férias e para aposentadoria, tudo isto pode ser incluído no contrato. Cláusulas adicionais podem incluir itens como um restaurante e até bôlsas

pelos membros, representará um passo para maior unidade ainda que existiriam os sindicatos independentes não filiados a êles.

39. E se o empregado individualmente consentir. 
de estudo para os filhos dos empregados. Em resumo, as disposições são incluídas ou não no contrato segundo os desejos e interêsses das partes, existindo sòmente uma ou outra regra ocasional de lei que seja obrigatória.

Neste respeito, pode-se notar que em geral não existe um prazo fixo para o contrato de trabalho, tal como existe no Brasil ${ }^{40}$. As partes simplesmente estipulam o prazo. Por consentimento mútuo, o contrato pode ser rescindido a qualquer tempo, e outrossim alterado favoràvelmente ou mesmo em prejuizo dos empregados pois não existe um equivalente à disposição brasileira proibindo alterações em prejuízo do empregado ${ }^{41}$.

Outra norma legal brasileira sem equivalente no sistema norte-americano é a restrição ao direito do empregador de transferir o empregado ${ }^{42}$. Pode ser estipulado no contrato, mas se não o fôr, o direito do empregador fica quase ilimitado neste respeito.

Outro ponto para ser notado é que nem o sindicato nem a emprêsa nos Estados Unidos tem limitações para observar quanto à nacionalidade tal como existem no Brasil, onde se exige que $2 / 3$ dos empregados sejam brasileiros ${ }^{43}$ e que $2 / 3$ dos salários sejam pagos a brasileiros ${ }^{44}$. Tal lei nos Estados Unidos, discriminando entre nacionais e estrangeiros, apresentaria sérios problemas constitucio-

40. No caso do contrato coletivo, 2 anos. Art. 620 . E interessante notar que contratos fora dêsse prazo podem ser executados pelo sindicato, mas não contra o trabalhador.

41. Art. 468, o qual se aplica sòmente ao contrato individual. Presumìvelmente o contrato coletivo pode ser alterado, mas como depende das exigências de homologação do Ministério e aprovação do sindicato parece que tal hipótese seria bastante dificil.

42. Art. 469 da C.L.T.

43. Art. 352 da c.L.T.

44. Art. 354 da C.L.T. 
nais, em nossa opinião, seria inconstitucional como infringente da garantia de igualdade ${ }^{45}$.

Usar a nacionalidade como critério para constituir um quadro de empregados entendemos ser proibido por legislação tal como a "Lei de Práticas Justas de Emprêgo" de Nova York (Fair Employment Practices Act).

Outro princípio brasileiro, o de igualdade de salário para estrangeiros e brasileiros prestando o mesmo serviço, não existe na lei norte-americana, mas no aspecto prático a igualdade fica assegurada porque nacionalidade não é usada como princípio para a determinação do salário e assim não existe discriminação.

O conceito de estabilidade para empregados não tem aceitação, nem legal nem consuetudinária, como tal nos Estados Unidos, mas o mesmo resultado aparece geralmente na prática, embora não seja de um modo tão uniforme como no Brasil. A estabilidade é obtida ou pelo contrato coletivo ou por entendimento tácito, e tem duas manifestações: primeira, quando os empregados são dispensados temporàriamente ou permanentemente, os que contém maior número de anos de serviço são os últimos a serem afetados; segundo, entende-se que quanto maior o número de anos de serviço, maior a expectativa do empregado ficar no emprêgo e tanto maior a dificuldade em encontrar e ajustar-se a um novo emprêgo. Por isso, o sindicato é especialmente zeloso em proteger os interêsses do empregado antigo e assim a demissão dêle em geral exige uma razão séria, tal como completa falta de habilidade, ineficácia elevada, falta de observância dos regulamentos da emprêsa motivos semelhantes aos incluídos no conceito de justa causa para demissão no Brasil) etc.

Considerando que quase tudo nos Estados Unidos é deixado no campo aa autonomia individual, é um pouco

45. De fato, parece difícil conciliar a lei brasileira com o artigo 141 da Constituição de 1946, assegurando igualdade perante a lei dos brasileiros e estrangeiros residentes no país. 
difícil para o norte-americano acostumar-se à idéia de regular quase todos os assuntos por lei, embora isto seja compreensível em vista da falta histórica de prática em sindicalismo no Brasil, e a necessidade consequente de proteger o trabalhador com normas legais. Em vista desta necessidade, não é surpreendente nem alarmante, ao norteamericano encontrar disposições na Consolidação das Leis do Trabalho regulamentando o seguinte: horário diârio semanal, pagamentos extraordinários para serviços fora do horário em certas condições, indenização para demissão injusta, licença para ausência da mulher grávida, férias, restaurantes para grandes estabelecimentos, não transferência sem aumento do salário, etc.

A grande desvantagem que o norte-americano encontra em tais disposições é o perigo de ser uma regra infeliz colocada na lei, onde pode ficar sem alterações devido a inércia e considerações políticas, embora seja melhor para o empregado e empregador que ela não exista. Na nossa opinião esta é a situação da regra brasileira de estabilidade. Como temos uma disposição semelhante mas particular nos Estados Unidos, o conceito mesmo não parece fora do normal. Não obstante, a forma adotada pela lei brasileira, não parece ser a resolução mais inteligente, devido a sua falta de flexibilidade e à pressão que impõe tanto sôbre empregado como empregador. Lembre-se a grande tentação para o empregador de tornar as condições do trabalho insuportáveis para o empregado próximo aos 10 anos de serviço, a fim de obrigá-lo a sair do emprêgo. Se o empregado ficar, estará descontente no emprêgo e as relações entre êle e a emprêsa serão de hostilidade. Se o empregado consentir em ser dispensado, então o propósito de estabilidade é derrotado. Se êstes dois aspectos são desfavoráveis ao empregado, a estabilidade, uma vez atingida muitas vêzes representa um problema verdadeiro para a emprêsa, que é obrigada a manter um empregado que nada contribui para ela e que pode passar o seu 
tempo de modo ainda mais prejudicial ao empregador, aproveitando-se da estabilidade da limitada possibilidade de demissão nos têrmos da falta grave. Já que o essencial básico na relação de trabalho é a satisfação mútua e a habilidade de funcionar juntos em harmonia, assim fazendo do emprêgo uma atividade humana mais importante que a simples troca de serviço pelo dinheiro, parece que seria prudente mudar o método atual, sem sacrificar o princípio da estabilidade. Embora possa parecer presunção de observador estrangeiro, desejaríamos lembrar que talvez um sistema mais satisfatório fôsse a instituição de uma escala flutuante na qual o prazo para estabilidade concedido ao empregado fôsse aumentando com os anos de serviço. Talvez fôsse também aconselhável incluir outros fatôres na escala, tais como tempo total como membro sindical, treinamento especial obtido pelo empregado para preparar-se para o emprêgo, mérito e habilidade demonstrados pelo empregador em unidade produzida ou atitude cooperativa ou a sua falta no registro disciplinar, etc. A justificação para introduzir fatôres outros que a mera antiguidade seria fornecer um incentivo para o trabalhador ganhar o estado de estabilidade, enquanto asseguraria ao empregador que seja merecido. Não conceder uma estabilidade vitalícia exceto nos casos de maior merecimento e talvez ainda nesse caso estipulando que a má execução do trabalho pelo empregado seria considerada falta grave, serviria para proteger o empregador caso o empregado tentasse aproveitar-se da condição de estabilidade para deixar de contribuir para a produção.

Até êste ponto, dois aspectos do direito social norteamericano têm sido destacados: $1^{\circ}$ ) que grande parte não é encontrada nas leis mas depende das partes; $2 .^{\circ}$ ) que a lei federal tem como fim assegurar que as partes negociem justamente entre si. Não obstante, a legislação estadual e federal venha assumindo um papel de crescente importância em assegurar certos direitos, papel geralmente 
no interêsse do empregado, que não podem ser perdidos por negociação, assim criando um núcleo de proteção, especialmente importante no caso de empregados não sindicalizados ou pertencentes a um sindicato fraco.

No campo de legislação federal, temos o "Fair Labor Standards Act" (Lei de Normas Justas de Trabalho) de $1938^{46}$, subsequentemente alterado. Como no caso de quase tôda a legislação federal, o seu alcance é limitado ao comércio interestadual, mas em vista da interpretação aumentada dêste conceito, pode-se dizer que se aplica à maioria dos trabalhadores. As suas disposições proibem o trabalho de menores ${ }^{47}$, estipulam o horário semanal normal de 40 horas, horário diário normal de 8 horas, e um salário mínimo nacional de 75 cents. por hora ${ }^{48}$. O horário diário e semanal podem ser aumentados pelo pagamento de certos adicionais mínimos, de $50 \%$ mais para as primeiras 8 horas adicionais, e de $100 \%$ para as demais. Não há limite sôbre horas totais. Disposições semelhantes, como é sabido, existem na lei brasileira.

Uma lei parecida aplica-se aos estabelecimentos que têm contratos com o govêrno federal ${ }^{49}$ : dispõe contra o trabalho de menores; estabelece o horário semanal de $\mathbf{4 0}$ horas; determina que o salário mínimo será aquêle geralmente em vigor na indústria da qual o estabelecimento faz parte ${ }^{50}$.

O equivalente norte-americano à Lei de Acidentes do Trabalho encontra-se em leis estaduais e federais chamadas "Leis de Responsabilidade do Empregado" (Employer Liability Acts). Em geral, estas dispõem que os acidentes

46. Statutes at Large, 1060, 1938.

47. Definido em têrmos de 16 anos.

48. É importante notar que quase ninguém recebe tão pouco. o mínimo atualmente em vigor para trabalho sindicalizado talvez possa ser estimado a $\$ 1.25$ por hora ou mais.

49. "Walsh-Healy Act of 1936".

50. Assim fornecendo um salário mínimo mais elevado que o mínimo nacional ordinário. Veja nota 48. 
sofridos no decurso do emprêgo devidos a falta do empregador são da responsabilidade dêle. Mais recentemente, "Leis de Compensação do Trabalhador" (Worksmen's Compensation Acts) têm aparecido em muitos Estados, baseando a responsabilidade do empregador no risco inerente à relação de trabalho, em vez de baseá-la na sua negligência. Embora esta legislação represente um melhoramento considerável quanto aos princípios do direito costumeiro, e embora muitos tribunais tenham ido longe no reconhecimento a negligência do empregador, e muitas legislações estaduais tenham suprimido a necessidade de provar essa negligência, ainda é justo dizer que a êste respeito os Estado Unidos fariam bem em seguir o exemplo do Brasil e adotar proteção universal do trabalhador baseada no risco da relação de trabalho em vez de ampliar o conceito de negligência patronal como ainda é o caso das leis federais e de muitos Estados. Não obstante, deve salientar-se que desenvolvimentos recentes nos contratos resultantes de negociação coletiva têm trazido extensivos planos de segurança contra acidentes, assim reduzindo algo da seriedade do problema.

A aposentadoria e o seguro de vida são garantidos pelo Sistema de Segurança Social (Social Security System) ${ }^{51}$, semelhante na forma ao sistema brasileiro dos Institutos de Aposentadoria e Pensões, com a excepção de ser uma única entidade centralizada para todos os tipos de empregados. Esta centralização talvez explique o grande êxito e eficiência do funcionamento do sistema nos Estados Unidos. Os fundos são obtidos por meio de desconto nos salários e pagamentos equivalentes por parte do empregador. Com o plano atual, a aposentadoria é possível em geral aos 65 anos. Em caso de morte, os beneficiários recebem pagamentos mensais. Em leis estaduais encon-

51. Inaugurado em 1935 e subsequentemente expandido para incluir a grande maioria dos assalariados. Pode ser suplementado por disposições do contrato de trabalho. 
tram-se disposições semelhantes às brasileiras. $\mathrm{O}$ trabalho do menor não é permitido. No Estado típico, o menor entre 14 e 16 pode trabalhar em certos tipos de emprêgo para um número específico de horas (muitas vêzes menos horas do que o maior pode trabalhar) ${ }^{52}$; um exame médico e um "certificado de trabalho" (um tipo de carteira) são exigidos. A êste respeito deve ser lembrado que a educação pública gratuita e compulsória é garantida para todos (até a idade de 16 anos na maioria dos Estados), e como os cursos noturnos não são facilitados em geral nem recomendados para o menor, o trabalho do menor ocorre nas férias do verão, em junho, julho e agôsto. Dos 16 anos aos 18, menos restrições são estipulados quanto ao tipo de emprêgo ou horário, mas exames médicos e certificado de trabalho são muitas vêzes exigidos. Em geral o menor nos Estados Unidos recebe o mesmo salário, ou virtualmente o mesmo, dos que prestam o mesmo serviço, e não a quase automática metade recebida pelo aprendiz como no Brasil ${ }^{53}$. É nossa opinião pessoal que parece difícil conciliar esta disposição brasileira com o princípio geral de salário igual para trabalho igual ${ }^{54}$ e, em segundo lugar, parece-nos infeliz por fornecer um incentivo para empregar menores ${ }^{55}$.

O emprêgo de mulheres nos Estados Unidos pode ser regulado pela lei, pelo contrato de trabalho ou por costumes locais. Não é normal, por exemplo, para elas trabalharem à noite, nem horas extraordinárias, a não ser nas épocas de emergência (guerra etc.. Licença para mulher

52. Não pode, por certo, ser empregado em uma indústria no comércio interestadual, pois êste violaria o "Fair Labor Standars Act"

53. De fato, a lei mesma fornece a base para isto no artigo 80 , tratando do salário mínimo.

54. Artigo 461.

55. Reconhecendo naturalmente, que em casos individuais pode ser de grande importância para o menor obter um emprêgo e que para êle a lei pode representar um auxílio tornando seus serviços mais atraentes à emprêsa. 
grávida é concedida normalmente. Em geral, a mulher recebe o mesmo salário que o homem no caso de serviços idênticos).

Como no Brasil, regras de higiene e segurança são colocados em lei. Em geral a legislação neste caso é estadual ou municipal e geralmente não é tão detalhada como a lei brasileira e deixa discreção aos fiscais de saúde que fazem inspeções periódicas. Aqui também a lei mesma não é tão importante como o contrato coletivo, porque os sindicatos têm sido muito eficazes em obter excelentes condições de trabalho e em conseguir atenção pronta às reclamações através da Comissão de Conciliação. Talvez seja efetivamente êste interêsse expresso dos trabalhadores no emprêgo que falta no Brasil e explica a falta de concretização na prática das normas muito avançadas das Leis de Trabalho.

Os princípios de direito comum não sòmence restringiram os direitos do empregado sindicalizado no passado mas também protegiam e ainda hoje protegem vários direitos de trabalho, apresentando resultados que são parecidos com os das disposições das leis brasileiras ou com os resultados prováveis em juízo no Brasil. Por exemplo, o empregado é considerado um credor quirografário quanto aos salários não pagos, na falência ou em outras circunstâncias. Esta preferência representa o mais respeitado crédito do direito costumeiro e sempre é reconhecido antes de qualquer outro crédito contra a emprêsa ${ }^{56}$.

Outro exemplo é que o trabalhador tem direito a um salário justo para serviços prestados e na falta de estipulação a respeito entre as partes, o tribunal estabelecerá a importância, tomando em consideração o tipo de emprêgo e o salário local em vigor ${ }^{57}$. Também o empregado tem o direito de executar o contrato. Se fôr por prazo determinado e o empregador o rescindir, o empregado tem

56. Disposições da Consolidação das "Leis do Trabalho" incluem férias não gozadas (Art. 144) e salários não pagos (Art. 449).

57. Disposição parecida encontra-se no Art. 460. 
direito a perdas e danos baseados no que teria ganho nos têrmos do contrato. Não obstante, como êle provàvelmente pode obter outro emprêgo e como o direito costumeiro impõe sôbre êle o dever de tentar arranjar tal emprêgo para mitigar a responsabilidade do empregador, em geral, o empregado não receberá os salários integrais, como no Brasil ${ }^{58}$. No caso de emprêgo com prazo indeterminado (chamado "a vontade"), não existe no direito costumeiro o princípio de indenização ou aviso prévio ${ }^{59}$. Normalmente êstes são estipulados no contrato e assim podem ser reconhecidos em juízo. Outro direito do empregado, como seria esperado, é de não ser insultado ou ferido pelo empregador, podendo receber indenização por danos em tais $\operatorname{casos}{ }^{60}$.

O trabalhador desempregado nos Estados Unidos tem não sòmente a secção de "Precisa-se" do jornal mas também: (1) muitas vêzes um serviço de empregos do sindicato; (2) o Serviço de Emprêgos dos Estados Unidos, uma agência do Ministério de Trabalho, com escritórios em tôdas as partes do país, com listas de emprêgos disponiveis; (3) serviços estaduais de emprêgos.

Se, apesar dêstes auxílios o trabalhador não pode achar um emprêgo sua situação torna-se menos infeliz em muitos Estados por meio do "seguro de desemprego", que consiste em pagamentos do govêrno estadual para tomar o lugar dos salários faltantes.

\section{IV - Conclusão}

Os sistemas de direito social brasileiro e norte-americano, têm distintas fontes históricas e orientações. Ao norte-americano, ter tantos assuntos disciplinados na lei

58. Artigo 479.

59. Artigo 487.

604 Também no Brasil o empregado pode considerar injustamente rescindido o contrato e a indenização é devida a êle. 
escrita parece deixar muito pouco às partes. Ao brasileiro, provàvelmente $o$ direito social norte-americano parece surpreendente na sua falta de ordem sistemática. Não obstante, o sistema norte-americano, depois de anos de esfôrço, tem resultado num sistema no qual a maior parte dos empregados podem ter casas próprias, automóveis, televisão, podem viajar, podem mandar seus filhos à Universidade, e, enfim, gozar de uma prosperidade material que possibilita um elevado nível de interêsse cultural - tudo com uma semana normal de 5 dias e 40 horas de trabalho. Isto aconteceu porque o trabalhador aprendeu como expressar-se de forma enérgica mas ao mesmo tempo razoàvelmente, e porque a classe patronal vem tratando a classe operária como um sócio no processo de produção e comércio. Se um sistema é fundado na lei escrita ou na iniciativa particular, o certo é que as relações trabalhistas bem sucedidas em última análise dependem das pessoas envolvidas. Quase qualquer lei pode ser ignorada e desrespeitada até ser morta, se o povo se negar observá-la. Por isso, é de esperar-se que o Brasil não deposite sua fé simplesmente nas leis, supondo que elas resolvam os problemas. Se as leis brasileiras, novas como são, vão desenvolver-se para o futuro, tanto os sindicatos como os empregados precisam ser educados nos métodos de trabalharem em conjunto. Básica para isto é a necessidade de os sindicatos aprenderem a exercitar com eficiência a "democracia própria", para que mereçam o respeito das emprêsas. Com sua progressiva e em geral excelente legislação, o Brasil poderia evitar a luta prolongada que foi necessária nos Estados Unidos para obter direitos básicos para o trabalhador. O Brasil só poderá atingir êsse objetivo se os trabalhadores, e, de sua parte, os empregadores se prepararem para inteligentemente defender seus direitos e negociar com compreensão com a outra parte. 0 processo de "collective bargaining" e o interêsse próprio esclarecido do qual depende, provàvelmente nunca assumirá no Brasil a mesma forma que nos Estados Unidos. 
Não obstante, se o sistema brasileiro quiser transformar-se num sistema em que haja "democracia própria", como é desejável num país que está se desenvolvendo tão ràpidamente, então passos decisivos deverão ser dados nessa direção

Tem chegado a ser quase uma tatologia concluir-se que a educação represente a solução para tôdas as necessidades humanas, mas neste caso parece mais uma vez ser verdade.

Êste artigo foi escrito na esperança de que as considerações nele contidas, sôbre um outro sistema de direito social, embora sumárias, possam contribuir para que o leitor compreenda melhor o seu próprio sistema, como aconteceu, aliás, com o autor em seus estudos relativos ao direito social brasileiro, e também para adiantar um pouco o processo de educação a êste respeito, procurando demonstrar, mais uma vez, que nenhum problema humano exige, necessàriamente, uma única solução. 